\title{
Economics
}

\section{and Business}

Review

\section{Volume 6 (20) Number $4 \quad 2020$}

\section{CONTENTS}

Editorial introduction

Ida Musiałkowska

\section{ARTICLES}

Inequality and politics in Brazil: Bolsa Familia and beyond

Ladislau Dowbor

Income gaps: Education and inequality

Julián Leone, Jorge Lo Cascio

Financial cooperation initiatives in Latin America: Conditions of origins, subsistence and eventual vanishing

Elia Elisa Cia Alves, André Martins Biancarelli

Searching for similarities in EU corporate income taxes for their harmonization Edyta Małecka-Ziembińska, Anna Siwiec

What determines the scale of state ownership in enterprises? Some evidence from post-socialist countries

Piotr Matuszak

Efficiency of services in CEE countries-case study of Poland and Belarus

Elżbieta Skąpska, Ewa Rollnik-Sadowska 


\author{
Editorial Board \\ Horst Brezinski \\ Maciej Cieślukowski \\ Gary L. Evans \\ Niels Hermes \\ Witold Jurek \\ Tadeusz Kowalski (Editor-in-Chief) \\ Jacek Mizerka \\ Henryk Mruk \\ Ida Musiałkowska \\ Jerzy Schroeder
}

\title{
International Editorial Advisory Board
}

Edward I. Altman - NYU Stern School of Business Ivo Bischoff - University of Kassel

Udo Broll - School of International Studies (ZIS), Technische Universität, Dresden

Conrad Ciccotello - University of Denver, Denver

Wojciech Florkowski - University of Georgia, Griffin

Oded Galor - Brown University, Providence

Binam Ghimire - Northumbria University, Newcastle upon Tyne

Christopher J. Green - Loughborough University

Mark J. Holmes - University of Waikato, Hamilton

Andreas Irmen - University of Luxembourg

Bruce E. Kaufman - Georgia State University, Atlanta

Robert Lensink - University of Groningen

Steve Letza - The European Centre for Corporate Governance

Victor Murinde - SOAS University of London

Hugh Scullion - National University of Ireland, Galway

Yochanan Shachmurove - The City College, City University of New York

Richard Sweeney - The McDonough School of Business, Georgetown University, Washington D.C.

Thomas Taylor - School of Business and Accountancy, Wake Forest University, Winston-Salem

Clas Wihlborg - Argyros School of Business and Economics, Chapman University, Orange

Habte G. Woldu - School of Management, The University of Texas at Dallas

\section{Thematic Editors}

Economics: Horst Brezinski, Maciej Cieślukowski, Ida Musiałkowska, Witold Jurek,

Tadeusz Kowalski • Econometrics: Witold Jurek • Finance: Maciej Cieślukowski, Gary Evans,

Witold Jurek, Jacek Mizerka • Management: Gary Evans, Jacek Mizerka,

Henryk Mruk, Jerzy Schroeder • Statistics: Marcin Anholcer, Maciej Beręsewicz, Elżbieta Gołata

Language Editor: Owen Easteal • IT Editor: Marcin Reguła

C Copyright by Poznań University of Economics and Business, Poznań 2020

Paper based publication

\section{ISSN 2392-1641 \\ e-ISSN 2450-0097}

POZNAŃ UNIVERSITY OF ECONOMICS AND BUSINESS PRESS

ul. Powstańców Wielkopolskich 16, 61-895 Poznań, Poland

phone +48 $618543154,+48618543155$

www.wydawnictwo.ue.poznan.pl, e-mail: wydawnictwo@ue.poznan.pl

postal address: al. Niepodległości 10, 61-875 Poznań, Poland

Printed and bound in Poland by:

Poznań University of Economics and Business Print Shop

Circulation: 215 copies 


\title{
Searching for similarities in EU corporate income taxes for their harmonization ${ }^{1}$
}

\author{
Edyta Małecka-Ziembińska ${ }^{2}$, Anna Siwiec ${ }^{3}$
}

\begin{abstract}
The purpose of this paper is to answer the question whether, despite the differentiation of the corporate income tax in the European Union, there are similarity patterns allowing for the harmonization of the bases of this tax. The analysed CIT static data both quantitative and qualitative concerns the years 2018 and 2020. The method of hierarchical cluster analysis allowed a grouping of EU countries according to their similarities. It also indicated the greatest tax differences between EU member states. In turn the affinity analysis made it possible to distinguish groups of countries which are similar in terms of CIT with the simultaneous identification of a pattern. Results show that despite significant differences in tax rates some EU states show convergence in tax bases. The geographical criterion still plays an important role in determining CIT structure and tax incentives are one of the tools that may be used in the approximation of the bases.
\end{abstract}

Keywords: corporate income tax, tax harmonization, European economic integration. JEL codes: F36, H25, H26, H32, H87, K34.

\section{Introduction}

The European Union (EU) is a common market with free movement of goods, services, persons and capital. It is also an area of different corporate tax systems. Such a combination of a highly integrated market and divergent taxes opens a field for tax competition but also for corporate abuse. Many researchers indicate tax harmonization as a solution. The question arises if there is really a place for it? How deep is corporate tax differentiation across EU coun-

\footnotetext{
${ }^{1}$ Article received 10 August 2020, accepted 7 December 2020.

2 Poznań University of Economics and Business, Institute of Finance, Department of Public Finance, Al. Niepodległości 10, 61-875 Poznań, Poland, corresponding author: edyta.maleckaziembinska@ue.poznan.pl, ORCID: 0000-0002-3398-809X.

${ }^{3}$ Poznań University of Economics and Business, Institute of Finance, Department of Public Finance, Al. Niepodległości 10, 61-875 Poznań, Poland, anna.siwiec@phd.ue.poznan.pl, ORCID: 0000-0002-8262-6511.
} 
tries? Are there systems similar to each other? Which of the tax features cause the greatest discrepancies? The awareness of the differences and similarities between EU states gives a greater chance for tax approximation. This is the right time for such questions as the European Commission is pushing for the abolition of unanimous voting on taxes which has been blocking such harmonization for years.

It is commonly known that CIT in the EU is highly diversified but the comparative research is mainly limited to quantitative data. Taxation cluster analyses are based mainly on grouping countries according to their tax burden and comparing statutory, effective or implicit tax rates (Korečko \& Ondrijová, 2019; Šimková, 2015; Lukáčová, Korečko, Jenčová, \& Jusková, 2020). This paper juxtaposes selected CIT quantitative and qualitative characteristics to reveal a picture of the similarity pattern in EU countries. The method of hierarchical cluster analysis comparing the main tax elements such as entities, bases and rates found similarities between countries' tax regulations. In turn the affinity analysis made it possible to distinguish groups of countries similar in terms of CIT with the simultaneous identification of a pattern. Finding certain similarities in tax structures may indicate further possible direction and useful tools leading to successful tax harmonization. Although tax rate harmonization turned out to be a too far-reaching step for EU countries, partial harmonization based on approximated tax bases still has a chance to be realized.

The following Eurostat data was taken into account: statutory (STR) and effective average (EATR) tax rates, as well as the CIT percentage share in GDP and in total tax revenues of each EU state. Taking into account that a part of the data is published by Eurostat with a delay, the quantitative analysis covers the year 2018 which delivered complete figures and comparability. The analysis was supplemented by following 2020 qualitative variables: corporate tax incentives, corporate taxation of partnerships, Controlled Foreign Corporation (CFC) rules, special tax rates for small and medium enterprises (SMEs), agriculture income taxation, group taxation. The data was retrieved from Taxes in Europe Database v. 3 published on the European Commission website. ${ }^{4}$

The paper is structured as follows: Section 1 presents the theoretical background and the literature review of tax harmonization; Section 2 presents the legal framework for direct taxes harmonization in EU; Section 3 delivers the outcomes of the research on tax harmonization organised by the European Commission; Section 4 presents the research method and the results obtained from the selected CIT characteristics comparison; The paper ends with discussion points and conclusions.

\footnotetext{
${ }^{4}$ https://ec.europa.eu/taxation_customs/tedb/taxDetails.html?id=50/1577833200
} 


\section{Theoretical background and literature review of tax harmonization}

The EU plays no direct role in establishing and collecting taxes. Sovereign states shape their tax policies independently. Any EU interference in national tax policies requires states' prior unanimous voting in the Council (Art. 113 of The Treaty amending The Treaty on European Union and The Treaty establishing The European Community (2007/C 306/01). The EU oversees national tax rules in some key areas and watches over fair competition and taxation to protect undistorted market function. However today in the age of globalization, digitalization and multinational enterprises (MNEs), when all markets are connected and capital is highly mobile such limited tax coordination, especially concerning corporate taxation, is not enough. Current EU solutions are ill-suited for the taxation of multinational companies. First, they treat each multinational group member as a separate entity, second, they aim to ensure that the right to tax is exercised where value is generated while very often determining such a location is difficult. Technical progress resulting in globalization has caused an increase in the complexity of economic phenomena, which in turn has had an impact on corporate taxation. Companies began to seek tax optimization strategies and states have limited capacities to raise funds from direct taxes. Asymmetries between competing EU countries have a significant impact on the entire region and may lead to marginalization of some countries (Małecka-Ziembińska, 2010). EU national tax policies would have to be approximated to ensure the taxation in the internal market is fair and does not discriminate against any market players. Keeping divergent tax policies in EU countries has enabled tax competition which is used by MNEs optimizing their tax liabilities by taking advantage of legal loopholes or even breaking the law. Profit shifting to low-tax jurisdictions causes corporate tax base erosion and growing tax gaps in many EU countries and that is why the fight against harmful tax evasion and tax avoidance is one of the EU priorities. Divergent national tax rules in EU member states can cause also a problem of double taxation, ineffective capital allocation and high company compliance costs. Even if not being perfect direct tax harmonization understood as a unification of rules for setting tax bases, seems to be the quite sensible solution to the problems arising from CIT differentiation. It could support fight against tax avoidance and resolve problem of double taxation.

Although harmonization of corporate taxes has been extensively researched and covered by numerous studies there is not its one binding definition created by law or in the literature. Some authors emphasize that what really matters is the desired degree of tax systems approximation in EU, not definitions (James $\&$ Oats, 1998). However this degree of tax approximation is understood differently by different authors and EU states. Tax harmonization has been defined 
as more or less advanced tax coordination (Dosser, 1973), cooperation among nations (Prest, 1979; Baldwin \& Krugman, 2004) or the adjustment of national fiscal policies that are necessary for proper functioning of the single market (Pîrvu, 2012). As a result of a trade-off between countries harmonization does not mean an optimal solution with one objective, it is rather a kind of approach, a search for the best possible compromise between economic imperatives resulting from a common market and the requirements of $\mathrm{EU}$ member states' autonomy (Tulai \& Serbu, 2005, p. 133). It is also worth remembering that harmonization may be worked out not only by the European institutions responsible for the legislation process (harmonization coordinated) or may result from the judgements of the Court of Justice of the European Union prohibiting national tax rules which violate EU rules (negative harmonization). It may also be spontaneous and forced by the market (Pîrvu, 2012).

CIT harmonization has been analysed from many points of view. The most frequent research and discussions concern mainly its feasibility due to differences between national tax systems and its influence on: tax competition and distortions in the internal market, states' budgets and their sovereignty, operative costs of MNEs and tax administrations, effective capital allocation, the EU position towards other economies, the influence on labour market, etc.. Different scopes of harmonization are considered including only tax rates, tax bases or both elements. This second scope, called the Common Consolidated Corporate Tax Base (CCCTB) is assessed as the most likely and preferred by the European Commission and that is why it will be taken into consideration in a further part of this article.

There are many sceptical voices about tax harmonization (Barry, 2010; Baldwin \& Krugman, 2004; Van der Hoek, 2003) but numerous researchers indicate that it shall rather have a positive influence on the internal market (e.g. Bettendorf et al., 2010; Devereux \& Loretz, 2010; Sørensen, 2004). It is underlined that tax harmonization shall limit many distortions such as the discriminatory treatment of foreign investments, small companies or even more effectively against those with smaller effectiveness (Devereux \& Loretz, 2010). Current tax systems are more beneficial for domestic investments because of the lack of international loss consolidation. Introduction of CCCTB with formula apportionment (FA) would decrease the dispersion of effective average tax rates (EATR) distribution and mitigate CIT differences between domestic and international investment (Devereux \& Loretz, 2010). Tax conditions for small and large companies differ even at the level of one country. Tax optimization available for large companies means that they can afford foreign expansion by developing subsidiaries. Harmonization shall bring better conditions of moving abroad also for small and medium companies (Devereux \& Loretz, 2008). Although some member states may lose out on CIT harmonization, the aggregate gain for the EU shall slightly increase (by $0.1 \%-0.2 \%$ ) due to more efficient capital allocation. In fact the effects of tax harmoniza- 
tion will depend on the financial instruments used to balance states' budgets in case of changes in effective CIT rates (Sørensen, 2004). Some researchers claim that potential CIT harmonization in EU is unlikely due to the big differentiation of national tax systems and point out that it should be considered together with the agglomeration forces which divide Europe into rich and poor nations (Baldwin \& Krugman, 2004). On the one hand rich countries, having permanent agglomeration advantages over poor peripheries, may set higher tax rates (agglomeration rent) and will not be interested in harmonizing tax rates downwards. On the other hand rates harmonization upwards would be detrimental for poorer countries. It means that tax harmonization does not necessarily restrict tax competition (Baldwin \& Krugman, 2004) but may it even foster (Barry, 2010).

Tax harmonization should be considered as an aspect of globalization. There is an economic correlation between trade globalization, income inequalities and economic policy. Globalization has exacerbated income and wealth disparities between European regions that may hinder the process of the European integration (Broll, Kemnitz, \& Mukherjee, 2019). European integration itself also leads to the increase of income inequalities between rich and poor countries. The governments using special tax policies and welfare programmes have only limited options to mitigate those income disparities (Broll et al., 2019). Today the tax policy used by a country influences the level of foreign investments, it also causes externalities on the other countries, especially when countries are economically integrated or neighbours. Tax competition and market mechanisms mean that the optimal tax policy depends not only on internal political decisions but also on taxation rules used in neighbouring countries (Małecka-Ziembińska, 2010). For example a one percent cut in the home CIT rate, raises inward foreign direct investment by around 3.3\% as well as profit shifting (de Mooij \& Ederveen, 2003). It was observed that some high-tax jurisdictions might be interested in having low-tax countries as neighbours. This would be a case of dealing with "tax complementarity", not "tax competition". This phenomenon can be explained through the fact that such high-tax jurisdictions are able to sustain higher tax rates because investors' profit shifting to a country with lower CIT is very often accompanied by greater sales and investments in the high-tax country which is usually more agglomerated or centrally-located (Barry, 2010, pp. 8-9).

Non-harmonized rates structures are admittedly considered to be weaker (Sinn, 1990) or stronger (Bettendorf et al., 2010) and are the cause of market disruption but they are not the only one. As the attempts to harmonize corporate tax rates proved unsuccessful recent research has focused on the possibility of harmonizing corporate tax bases. More attention has lately been paid to one of their elements - tax incentives. It was noticed that EU countries use similar incentives to reduce the gaps in tax burdens in a way that they lead to tax harmonization (Bustos-Contell, Climent-Serrano, \& Labatut-Serer, 2020). 
The harmonization of corporate tax bases (partial harmonization) has also been thoroughly examined and chosen as the preferred solution by the European Commission. This harmonization project known as the Common Consolidated Corporate Tax Base (CCCTB) will be presented in the next section of this paper. There are many caveats and objections concerning CCCTB: no substantial welfare gains or unequal welfare distribution (Barry, 2010; Bettendorf et al., 2010; van der Hoek, 2003). Some scholars also underline that even tax coordination is not necessary because countries have sufficient tools for their individual fight against avoidance of taxation, e.g. Controlled Foreign Corporation Rules (Clifford, 2019). The fact is that, due to asymmetric treatment of profit-making and loss-making companies under CIT, makes tax gap estimations harder (International Monetary Fund, 2018), is used for tax planning by MNEs and needs an international common solution to the problem.

One of the arguments against tax harmonization is that it would destroy competition while recently some researchers have noticed that partial harmonization shall not reduce tax competition in EU and may lead to further divergence in tax rates across EU member states (Bettendorf et al., 2010; de Mooij, Liu, \& Prihardini, 2019). The question is, whether there is still place for rates reduction and if the introduction of uniform rules for determining the tax base would really have a negative influence on tax competition.

Some authors pay attention to the fact that introduction of CCCTB with FA will reduce the possibility of implementation by countries where legislative changes are needed as a result of changing economic circumstances (Barry, 2010). However it is worth considering that the adoption of common harmonized solutions shall provide greater legal and economic certainty for the taxpayers.

Finally the argument that CCCTB enactment would reduce EU attractiveness for investors from the other economies (Barry, 2010) seems to be not necessarily accurate. Transparent and unified tax regulations not only will not limit the choice and attractiveness of investment locations in the EU but should make the process easier and more conscious (European Commission, 2018a).

\section{Legal framework for direct tax harmonization}

The legal framework for harmonizing direct taxes has been developing very slowly with the first directives in 1990. Previous attempts to approximate corporate taxation took place mainly through EU soft law. ${ }^{5}$ There is a visible disproportion in EU legal regulations of direct and indirect taxes. Due to the needs of the customs union and thanks to having a direct legal mandate the EU has

${ }^{5}$ EU measures such as guidelines, recommendations, declarations, opinions which are not binding on their addressees. 
already harmonized indirect taxes such as value added tax (VAT) and excise duties. There is no such direct legal mandate for the EU to harmonize direct taxes: they still remain the sole responsibility of the member states. However EU treaties has provided an indirect mandate for such harmonization. The article 115 of the Consolidated version of The Treaty on the functioning of the European Union (2012) states that the Council "acting unanimously in accordance with a special legislative procedure and after consulting the European Parliament and the Economic and Social Committee", may issue directives approximating EU member states' regulations directly affecting the establishment or functioning of the internal market.

Currently binding legal acts relating to the approximation of direct taxation in EU are an expression of the agreement reached by the EU member states and concern solutions for double taxation connected with cross-border transactions (Council Directive 2011/96/EU, 2009/133/EC, 2003/49/EC, Convention 90/436/EEC), lack of taxation (Council Directive 2016/1164) or administrative cooperation between member states within the field of taxation (Council Directive 2011/16/EU). Special attention should be paid to the more comprehensive solution presented by the European Commission in its directive proposal on CCCTB (last version on 2016).

The idea of CCCTB comes down to the harmonization of the corporate tax basis, leaving the regulation of tax rates at the discretion of member states. This solution has been blocked by EU states but still has the best chance of being implemented in case the binding unanimous voting on taxes is abolished. That is why it will be dealt with in the next section.

Harmonization is criticized and effectively blocked by particular EU member states but the European Commission has lately intensified its tax-approximation activity and in 2019 issued a communication on more effective decisionmaking by qualified majority voting in some areas, including taxes. ${ }^{6}$ Owing to passerelle clauses introduced in 2016 to The Consolidated versions of the Treaty on European Union and the Treaty on the Functioning of the European Union (art. 48), there is a possibility in some areas to shift from unanimous decision-making to qualified majority voting (QMV) and from the consultation decision to codecision. ${ }^{7}$ Taxes belong to the most sensitive areas and are still subject to the unanimous voting rule. Nonetheless the introduction of passerelle clauses and the debate started by the Commission on a gradual transition to QMV increases the probability of direct tax harmonization. If there were an approved shift to QMV on taxes the harmonization of direct taxation would significantly accelerate. The question is if there is a chance for a bottom-

\footnotetext{
${ }^{6}$ Communication from the Commission to the European Parliament, the European Council and the Council of 15 January 2019, Towards a more efficient and democratic decision making in EU tax policy (COM(2019) 0008).

${ }^{7}$ https://eur-lex.europa.eu/legal-content/EN/ALL/?uri=CELEX:12016M048
} 
up harmonization resulting from national corporate taxes gradual approximation. This paper will try to verify it.

\section{Corporate tax harmonization research organised by the European Commission}

The European Commission has been the main advocate of corporate tax harmonization and outsourced extensive research on the impact of different business taxation on the common market. Following the pro-harmonization reports of Commission de la Communauté Économique Européenne (1962) and Commission of the European Communities (1970) in 1985 the European Commission issued the White Paper on Completing the Internal Market (Milan, $\operatorname{COM}(85) 310$ final). ${ }^{8}$ This document indicated the need for the removal of obstacles between European firms arising from the tax treatment of parents and subsidiaries, taxation of mergers, avoidance of double taxation. These postulates changed into legal solutions in the form of directives.

The Ruding Report (1992) indicated that tax differences in the European Community were the main reason for companies' international tax planning, high compliance costs, lack of transparency and source of tax rules' uncertainty due to frequent changes in tax legislation. The Ruding Committee suggested the removal of discriminatory tax arrangements, determining common rules for a minimum tax base and setting a minimum corporate tax rate, introducing transparency in tax incentives granted by the states (Ruding Report, p. 11). The European Commission also paid attention to the fact that tax competition caused by capital mobility resulted in a shift of the tax burden to less mobile tax bases such as labour which contributed to the increase of unemployment in EU. A proposed solution was the tax package ${ }^{9}$ and its key document - The Code of conduct for business taxation (Council of the European Union, 1997) - a non-legally binding instrument used for tackling harmful competition. The Bolkestein Report (Bolkestein, 2000) indicated that differences in statutory corporate tax rates heavily influenced investment decisions in the EU. Later on from the reports of Ruding and Bolkestein an idea emerged of CCCTB worked out by the European Commission (2016). CCCTB is a single set of rules to calculate companies' taxable profits in the EU according to their business activities in particular member states. Together with formula apportionment, it creates the possibility to calculate the tax basis on the European level and to assign it to the concerned member states according to special criteria. These shall be

\footnotetext{
${ }^{8}$ White Papers are documents containing proposals for European Union for action in a specific area.

9 Towards tax co-ordination in the European Union, https://eur-lex.europa.eu/legal-content/EN/TXT/PDF/?uri=CELEX:51997DC0495\&from=EN
} 
three equally weighted factors (i.e. labour, assets and sales by destination). It is worth noting that countries would still apply their national tax rates.

Companies could offset their losses in one EU member state against profits made in another member state. CCCTB would be mandatory for companies with a consolidated turnover above EUR 750 million. Small and medium enterprises could choose CCCTB optionally. This solution is limited to the unification of the rules for determining the tax base and aimed at achieving greater transparency of tax systems and reducing the compliance costs of MNEs.

The impact of CCCTB implementation has been analysed by the Commission's working group, the Joint Research Centre (CORTAX model) and the Centre for European Economic Research (ZEW, Tax Analyzer Model). The analysis included CCCTB application to multinationals and to all companies. The CORTAX model was used for the examination of formula apportionment, tax revenues for the EU-28 and assessing the impact of CCCTB on the main economic variables such as investment, employment, wages, GDP (Gross Domestic Product) and welfare. The results of the simulations suggest a positive effect on all key economic variables but a small decrease in total tax revenues for EU28. That decrease of $0.08 \%$ of GDP corresponding to about EUR 11 billion was due to tax reform and lower corporate tax revenues by about EUR 36 billion partly compensated by the increased revenues from other taxes by about EUR 25 billion. This change in the EU structure of tax revenues would result from a simple dependence: lower corporate taxes would cause increased economic activity of companies, higher employment and higher revenues from consumption and labour taxes.

A ZEW study was focused mainly on debt financing, research and development $(\mathrm{R} \& \mathrm{D})$ investments and tax planning in companies. The research showed that cross-border tax planning used by multinationals caused a considerable reduction of the effective taxation level. Results showed also a debt bias on capital cost and $\mathrm{R} \& \mathrm{D}$ underinvestment. The CCCTB providing equal deductions for debt and equity financing and R\&D reliefs was assessed positively by ZEW researchers. According to the results presented in European Commission (2016), CCCTB with an FA based on three equivalent items (i.e. assets, employment and turnover) would give the possibility to allocate fairly companies' income to the place of profit generation. Such an apportionment is more resistant to aggressive tax planning than the transfer pricing methods. The reform shall also decrease companies compliance costs by $62 \%-67 \%$ (for new subsidiaries) and $8 \%$ (of recurring compliance costs) in existing companies. The estimated value of recurrent cost reduction where the CCCTB is applied to all MNEs would bring EUR 0.8 billion (European Commission, 2016, p. 39). CCCTB would be then an effective tool to support economic growth and tax fairness. 


\section{Research method and results from the selected CIT characteristics comparison}

Hierarchical clustering algorithm groups the most similar objects into clusters. At the same time it tries to find the most dissimilar clusters. The main difference distinguishing this algorithm from other types of clustering algorithms is the construction of the dendrogram. It is a similarity tree describing relationships between nested overlapping clusters. As opposed to other clustering methods it reveals the broad and hierarchical structure of similarities between clustered objects. The result of the clustering depends strongly on the similarity measurement of the compared objects. A domain-specific measure of similarity is used to rank objects according to the value of the attributes that describe them. In addition larger sub-clusters are compared using different strategies expressed by the objective or loss function. The simplest one compares the two most similar objects representing two different compared clusters (singlelinkage clustering). Another one computes the similarity between all pairs of objects from both clusters and relates cluster similarity to the least similar objects from both clusters (complete linkage clustering). Yet one, finds centroid objects and compares them using similarity function. Every objective function gives a slightly different result of clustering. For the analysis conducted in this paper a complete linkage method was used called also the farthest neighbour clustering. By using such an objective function the obtained clusters became internally more coherent and compact. It happens because the farthest neighbour clustering maximizes distance between clusters or minimizes similarity. So if $X$ and $Y$ are clusters then distance between clusters is calculated according to $D(X, Y)=\max _{x \in X, y \in Y} d(x, y)$, where $x$ and $y$ are individual objects (countries) and $d(x, y)$ is a distance between them (inverse of similarity).

The calculation of similarity between objects was carried out using the weighted average. It was applied to aggregate normalized partial similarities computed according to the description in Table 1. A weight used for each attribute was equal thus no attribute was preferred. Technically data was processed in the R environment using the hclust algorithm (R Core Team, 2020) and visualized using the dendextend package (Galili, 2015).

Depending on the scope of the analysed CIT characteristics, four different groupings of EU countries were performed. Most features relating to both the entity, tax base and CIT rate were included in the first dendrogram (Figure 1). The second dendrogram (Figure 2) includes only those characteristics relating to the tax base. The third dendrogram (Figure 3) groups countries according to the characteristics of the applied tax incentives. The fourth dendrogram (Figure 4) includes the variables related to the tax burden. All variables are presented in Table 1. 
Table 1. CIT characteristics included in cluster dendrograms and their normalization

\begin{tabular}{|c|c|c|c|}
\hline $\begin{array}{c}\text { Dendrogram } \\
\text { number }\end{array}$ & $\begin{array}{l}\text { Compared CIT } \\
\text { characteristics }\end{array}$ & Type of attribute & $\begin{array}{l}\text { Partial } \\
\text { similarity } \\
\text { measure }\end{array}$ \\
\hline \multicolumn{4}{|c|}{ Characteristics related to the entity, tax base and rate } \\
\hline \multirow[t]{7}{*}{ Figure 1} & Partnerships liable to CIT & Binary (Yes/No) & \multirow{5}{*}{$\begin{array}{l}\text { Hamming dis- } \\
\text { tance }\end{array}$} \\
\hline & Group taxation & Binary (Yes/No) & \\
\hline & $\begin{array}{l}\text { Income from agriculture } \\
\text { taxation }\end{array}$ & Binary (Yes/No) & \\
\hline & $\begin{array}{l}\text { Special rate for SMEs } \\
(2020)\end{array}$ & Binary (Yes/No) & \\
\hline & CFC rules (ATAD) & $\begin{array}{l}\text { Binary (Yes - taxation all } \\
\text { income / No - taxation } \\
\text { only passive income) }\end{array}$ & \\
\hline & $\begin{array}{l}\text { Combined corporate in- } \\
\text { come tax rate (nominal } \\
\text { plus surcharges) (2020) }\end{array}$ & Real value (rates) & $\begin{array}{l}\text { Distance be- } \\
\text { tween normal- } \\
\text { ized values }\end{array}$ \\
\hline & Tax incentives & $\begin{array}{l}\text { Real value (average from } \\
\text { three binary similarities: } \\
\text { incentives: for R\&D, hu- } \\
\text { man factor support and for } \\
\text { particular sectors) }\end{array}$ & $\begin{array}{l}\text { Normalized } \\
\text { Hamming dis- } \\
\text { tance }\end{array}$ \\
\hline \multicolumn{4}{|c|}{ Characteristics related to the tax base } \\
\hline \multirow[t]{3}{*}{ Figure 2} & $\begin{array}{l}\text { Income from agriculture } \\
\text { taxation }\end{array}$ & Binary (Yes/No) & \multirow[t]{2}{*}{$\begin{array}{l}\text { Hamming dis- } \\
\text { tance }\end{array}$} \\
\hline & CFC rules (ATAD) & $\begin{array}{l}\text { Binary (Yes - taxation all } \\
\text { income / No - taxation } \\
\text { only passive income) }\end{array}$ & \\
\hline & Tax incentives & $\begin{array}{l}\text { Real value (average from } \\
\text { three binary similarities: } \\
\text { incentives: for } \mathrm{R} \& \mathrm{D} \text {, hu- } \\
\text { man factor support and for } \\
\text { particular sectors) }\end{array}$ & $\begin{array}{l}\text { Normalized } \\
\text { Hamming dis- } \\
\text { tance }\end{array}$ \\
\hline \multicolumn{4}{|c|}{ Types of incentives } \\
\hline \multirow[t]{3}{*}{ Figure 3} & Incentives for $\mathrm{R} \& \mathrm{D}$ & Binary (Yes/No) & \multirow{3}{*}{$\begin{array}{l}\text { Hamming dis- } \\
\text { tance }\end{array}$} \\
\hline & $\begin{array}{l}\text { Incentives for human fac- } \\
\text { tor support }\end{array}$ & Binary (Yes/No) & \\
\hline & $\begin{array}{l}\text { Incentives for particular } \\
\text { sectors }\end{array}$ & Binary (Yes/No) & \\
\hline
\end{tabular}




\begin{tabular}{|c|c|c|c|}
\hline $\begin{array}{c}\text { Dendrogram } \\
\text { number }\end{array}$ & $\begin{array}{c}\text { Compared CIT } \\
\text { characteristics }\end{array}$ & \multicolumn{2}{|c|}{$\begin{array}{c}\text { Partial } \\
\text { similarity } \\
\text { measure }\end{array}$} \\
\hline \multirow{5}{*}{ Figure 4 4} & $\begin{array}{c}\text { Combined corporate in- } \\
\text { come tax rate (nominal } \\
\text { plus surcharges) (2018) }\end{array}$ & Real value (rates) & \multirow{2}{*}{$\begin{array}{c}\text { Distance be- } \\
\text { tween normal- } \\
\text { ized values }\end{array}$} \\
\cline { 2 - 3 } & CIT as \% of GDP (2018) & Real value (percentage) \\
\cline { 2 - 3 } & $\begin{array}{c}\text { CIT as \% of total tax rev- } \\
\text { enue (2018) }\end{array}$ & Real value (percentage) & \\
\cline { 2 - 3 } & $\begin{array}{c}\text { Effective average tax rates } \\
(2018)^{*}\end{array}$ & Real value (rates) & \\
\hline
\end{tabular}

* Large corporations in the non-financial sector (computed at corporate level, for average asset composition and funding sources).

Source: Own calculation based on: (European Commission, DG Taxation and Customs Union).

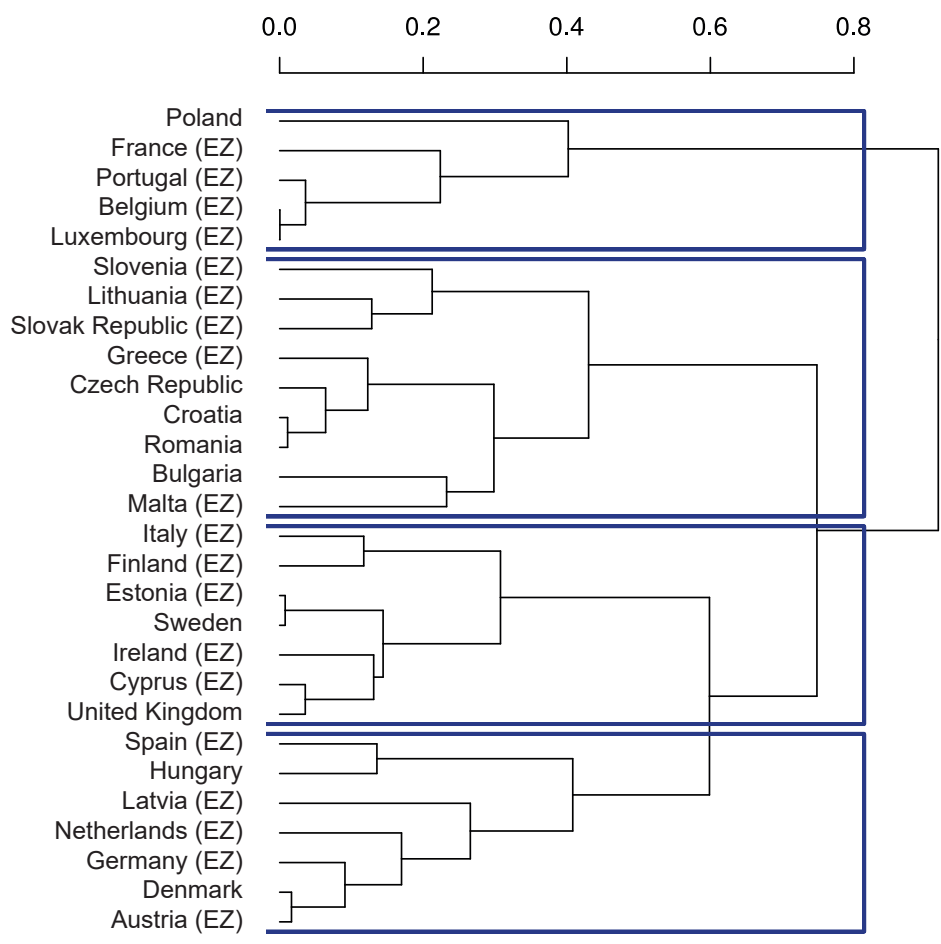

Figure 1. Hierarchical clustering of the EU28 countries according to the seven CIT characteristics related to the entity, tax base and rate in 2020

EZ - Euro Zone.

Source: As in Table 1. 
In Figure 1 the hierarchical clustering algorithm was based on three kinds of measures describing the widest scope of CIT features similarities. Five qualitative features described in binary $Y$ or $N$ attribute concerned the tax base width (partnerships, income from agriculture), its protection (CFC rules) and amenities for the taxpayers (group taxation, special rates for SMEs). Clustering allowed numerous groups of countries with different degree of similarity to be distinguished. Differences between EU countries were measured by the Hamming distance $\left(D_{H}\right)$-a metric comparing two binary data strings of equal length and showing the number of bit positions in which the two bits are different. Countries with the smallest number of differences were clustered closest. There is no visible dependence of the CIT structure on belonging to the euro area but noticeable similarities occur in the geographical layout. With few exceptions countries with similar CIT features belong to the same regions: BelgiumLuxembourg, Croatia-Romania, Czech Republic-Bulgaria-Greece, AustriaDenmark-Germany-Netherlands, Sweden-Estonia-Finland, Portugal-France. Geographically only Poland does not fit in the last cluster.

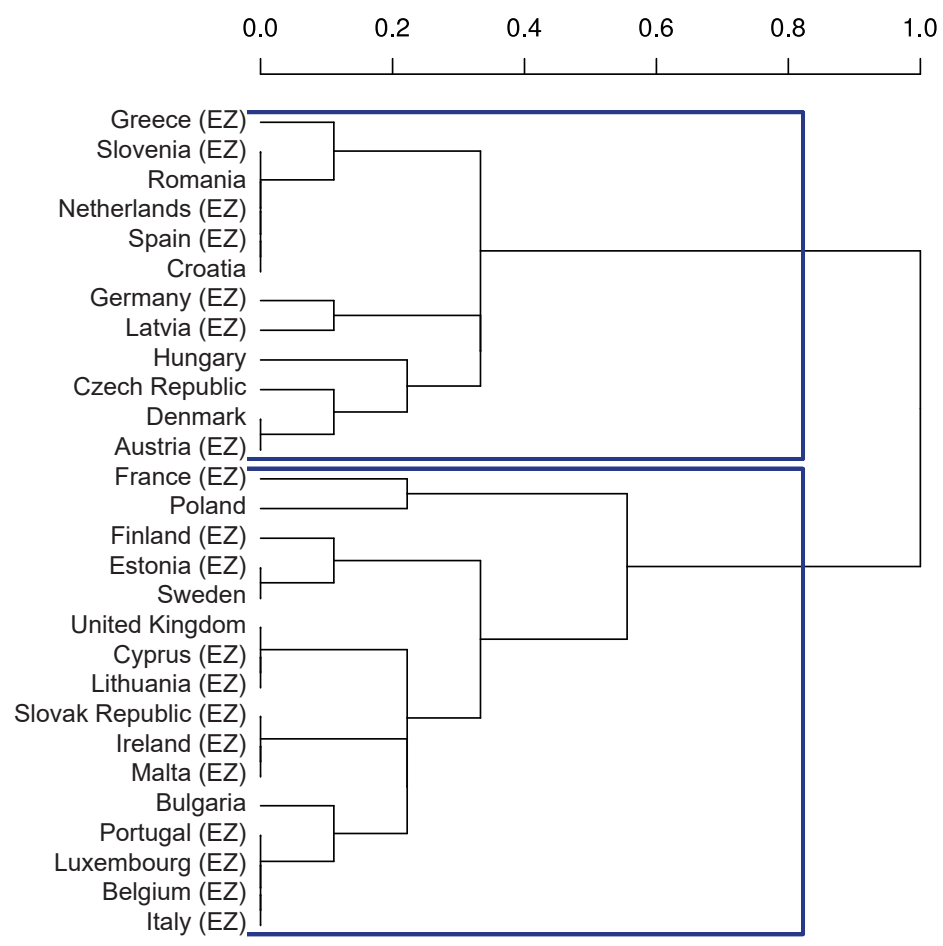

Figure 2. Hierarchical clustering of the EU28 countries according to the three CIT characteristics related to the tax base in 2020

EZ - Euro Zone.

Source: As in Table 1. 
In Figure 2 the analysis was limited to three CIT features concerning the tax base. Groupings from Figure 1 were repeated in Figure 2 but the results showed a much greater similarity in tax bases between EU countries. The division into two groups of countries was caused by the differentiation in CFC taxation. In sixteen countries, the CFC rules apply to all income while in twelve countries - only to the passive. Taxation of income from agriculture is a standardized element. According to information gathered by the European Commission the majority of countries (apart France and Poland) declare a legal possibility of applying corporate taxation to some income from agriculture (e.g. for corporation farms $)^{10}$. The differences within clusters result mainly from the different scope of tax incentives. In the first cluster (with CFC rules applying to passive income) there are two groups of countries with the greatest similarity but differentiated within the scope of tax incentives. The group with nine countries (from Slovenia, to Spain) predicts all types of tax incentives (for R\&D, human

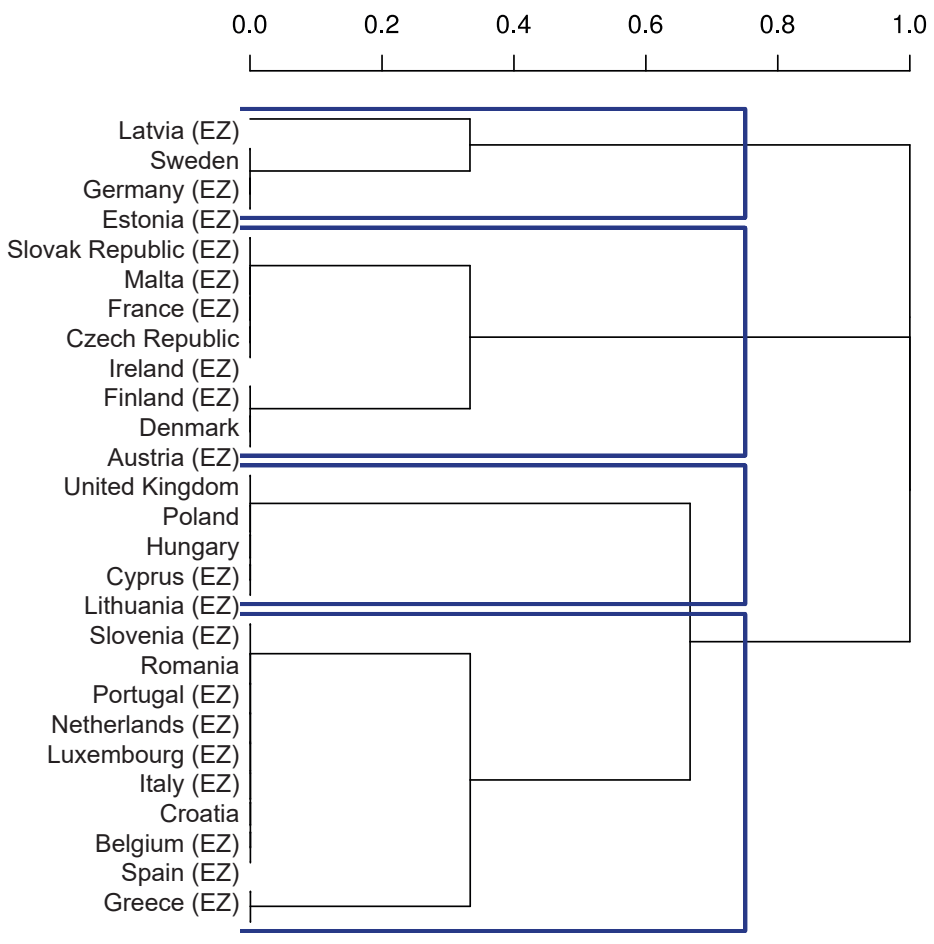

Figure 3. Hierarchical clustering of the EU28 countries according to the three types of incentives in CIT in 2020

EZ - Euro Zone.

Source: As in Table 1.

${ }^{10}$ https://ec.europa.eu/taxation_customs/tedb/taxDetails.html?id=50/1577833200. 
factor and for sectors/regions). Denmark and Austria focus mainly on tax incentives supporting R\&D.

Continuing the top-down analysis and making it narrower, resulted in the comparison of tax incentives. Tax allowances, incentives and reliefs (tax incentives) are used in almost all EU countries (apart Germany, Estonia and Sweden) and have different nomenclature. For the purpose of the analysis tax incentives have been divided into three types, in order from most popular to less used: 1) R\&D (i.e. costs of know-how, patents, innovation centers), 2) special solutions for particular sectors (i.e. agriculture, audiovisual) of the economy or weaker regions (i.e. with high unemployment), 3) human factor support support for social groups (unemployed, handicapped, elderly, scientific workers, worker training, creating new jobs). Tax incentives for R\&D are used in twenty two EU countries but the popularity of the other reliefs is comparable. Special solutions for particular sectors or regions are used by seventeen EU countries, and human factor support - by sixteen EU countries. As mentioned nine countries apply all the types of the mentioned solutions. The majority of EU states show tax convergence in this area and the geographical key loses its importance in this case.

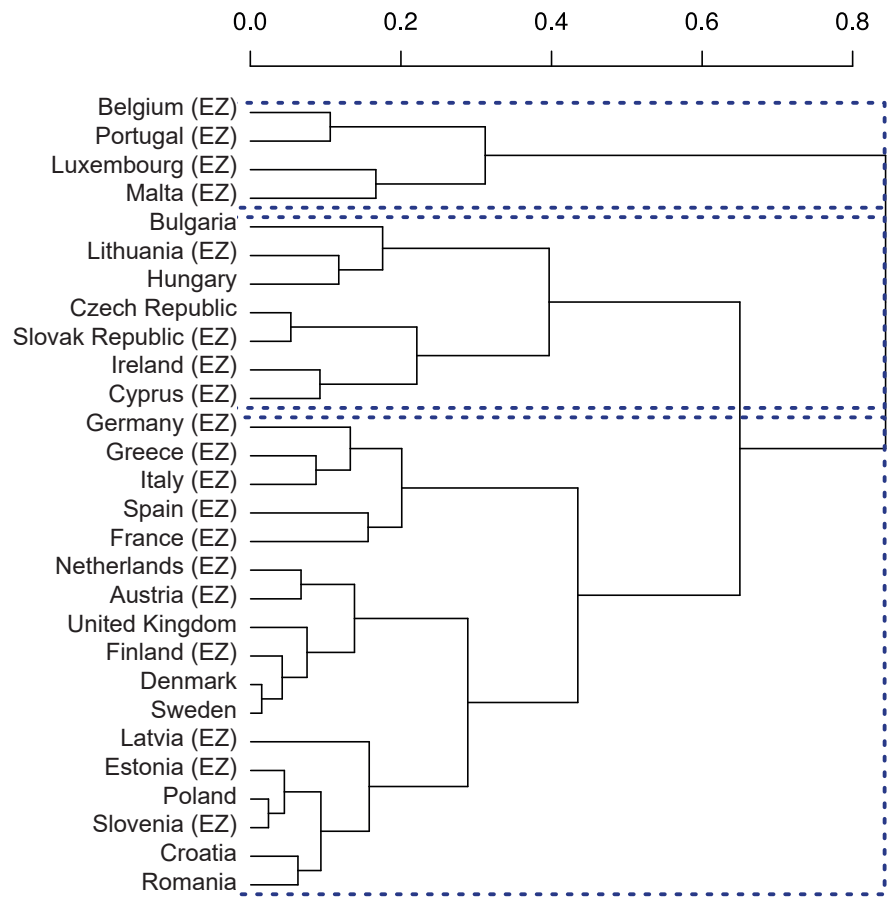

Figure 4. Hierarchical clustering of the EU28 countries according to the four CIT characteristics related to the tax burden

EZ - Euro Zone.

Source: As in Table 1. 
Table 2. CIT rates in 2018

\begin{tabular}{|c|c|c|c|c|}
\hline Member State & $\begin{array}{c}\text { STR - } \\
\text { combined } \\
\text { corporate } \\
\text { income tax rate } \\
\text { (nominal plus } \\
\text { surcharges) } \\
\text { in } \%\end{array}$ & $\%$ of GDP & $\begin{array}{c}\% \text { of total tax } \\
\text { revenue }\end{array}$ & EATR in \% \\
\hline France & 34.4 & 2.3 & 5.0 & 33.4 \\
\hline Spain & 25.0 & 2.3 & 6.6 & 30.1 \\
\hline Germany & 29.9 & 1.0 & 2.5 & 28.9 \\
\hline Greece & 29.0 & 2.2 & 5.6 & 27.6 \\
\hline Belgium & 29.6 & 4.3 & 9.6 & 24.9 \\
\hline Italy & 27.8 & 1.8 & 4.2 & 24.6 \\
\hline Malta & 35.0 & 5.5 & 17.4 & 24.4 \\
\hline Austria & 25.0 & 2.5 & 5.9 & 23.1 \\
\hline Luxembourg & 26.0 & 5.8 & 14.8 & 22.8 \\
\hline Netherlands & 25.0 & 3.1 & 7.9 & 22.5 \\
\hline Portugal & 31.5 & 3.3 & 9.6 & 21.4 \\
\hline United Kingdom & 19.0 & 2.6 & 7.7 & 20.6 \\
\hline Denmark & 22.0 & 2.7 & 6.1 & 19.8 \\
\hline Finland & 20.0 & 2.5 & 6.0 & 19.6 \\
\hline Sweden & 22.0 & 2.8 & 6.4 & 19.4 \\
\hline Slovak Republic & 21.0 & 3.3 & 9.6 & 18.7 \\
\hline Poland & 19.0 & 2.1 & 5.9 & 17.5 \\
\hline Slovenia & 19.0 & 1.9 & 5.1 & 17.3 \\
\hline Latvia & 20.0 & 1.1 & 3.4 & 16.7 \\
\hline Czech Republic & 19.0 & 3.5 & 9.7 & 16.7 \\
\hline Estonia & 20.0 & 2.0 & 6.1 & 15.7 \\
\hline Croatia & 18.0 & 2.3 & 5.9 & 14.8 \\
\hline Romania & 16.0 & 1.8 & 6.9 & 14.7 \\
\hline Ireland & 12.5 & 3.2 & 14.2 & 14.1 \\
\hline Lithuania & 15.0 & 1.5 & 5.1 & 13.6 \\
\hline Cyprus & 12.5 & 4.0 & 11.9 & 13.0 \\
\hline Hungary & 10.8 & 1.2 & 3.2 & 11.1 \\
\hline Bulgaria & 10.0 & 2.2 & 7.5 & 9.0 \\
\hline
\end{tabular}

States arranged from highest to lowest EATR.

Source: Grouping made by authors on the basis of European Commission, DG Taxation and Customs Union, based on Eurostat data. 
As a result of the hierarchical clustering of EU states according to the tax burden the numerous groups of states with a similar CIT share in GDP and in total tax revenue are visible, but not necessarily with similar statutory tax rates. Figure 4 should be analysed together with Table 2 detailing all tax features taken into account when calculating the tax burden. In Table 2 states were arranged from the highest to lowest EATR, clustering in Figure 4 provides a broader analysis. Both analyses suggest that tax rates are the most differentiating CIT feature and that states with similar STR are not similar in tax burden (e.g. Luxembourg with an STR of 26\% and Malta-STR 35\% but a similar share in GDP, respectively $5.8 \%$ for Luxembourg and $5.5 \%$ for Malta).

Taking into account the statutory tax rates in 2018 (Table 2), EU member states can be divided into three distinct groups: those with high (ranging between 25 and 35\%) STR (eleven states), medium STR (between 15 and 25\%, thirteen states) and low rates (below $15 \%$, four states). The similarity of statutory tax rates corresponds to the geographical proximity of countries.

A traditional grouping of countries based on STR changes when other tax burden indicators are taken into account. A few states with low or medium STR have a high CIT share in GDP and in total tax revenue (Ireland, Cyprus, Belgium, Czech Republic, Slovak Republic) which is explained by the use of a broader tax base (Cyprus, Belgium) or using attractive tax incentives, especially in R\&D. This is in line with the results of the analysis from Figures 3 and 4. The EATR showing the real capital burden in EU states is of crucial meaning for identifying the effect of taxation on discrete location choices ${ }^{11}$. In the case where locations are mutually exclusive the one with a lower EATR will be more attractive for investors. The application of tax reliefs, exemptions or incentives may significantly reduce the tax burden and such solutions are very often used by so-called "smart tax havens" such as Malta or Luxembourg. To summarize, tax rates are the most diversifying element in CIT structures and there is very small probability of their harmonization. On the other hand tax bases bring the possibility of tax harmonization and tax incentives may be a useful tool in this process. The analysis results show the repetition of similarity patterns. Some states are similar in CIT solutions (from Figures 1 to 3 or even 4). They mainly belong to the same geographical region i.e.: Belgium-Luxembourg, CroatiaRomania-Bulgaria-Czech Republic, Estonia-Sweden-Finland, Ireland-United Kingdom, Austria-Denmark-Germany-Netherlands.

In order to clarify whether there are any co-occurrences between CIT features in each country an affinity analysis has been applied. Affinity analysis is a popular method for searching for patterns in sets of data. It relies on association rules learning. For given set of items $I=\left\{i_{1}, i_{2}, \ldots, i_{k}\right\}$ describing features of objects and database containing transactions (sets of items) $T=\left\{t_{1}, t_{2}, \ldots, t_{n}\right\}$, the problem of association rules learning is a problem of finding all maximal

${ }^{11}$ EATR is measured as the proportion of total income taken in tax in each location (state). 
frequent of item-sets $X=\left\{X_{1}, X_{2}, \ldots, X_{m}\right\}$, where $X_{1}, \ldots, X_{m} \in I$ with support in equal or greater than given minimum support threshold. In this case items denote features of CIT and transactions denote EU countries.

Affinity analysis could give information about similarities of corporate tax systems between EU countries and indicate the features of CIT that may form the basis for future harmonization. Affinity analysis works, in principle, on discrete data and requires its earlier preparation. For this purpose a frequent item-sets mining method was used. In this case the algorithm Eclat has been

Table 3. Frequent item-sets of CIT common features in EU states

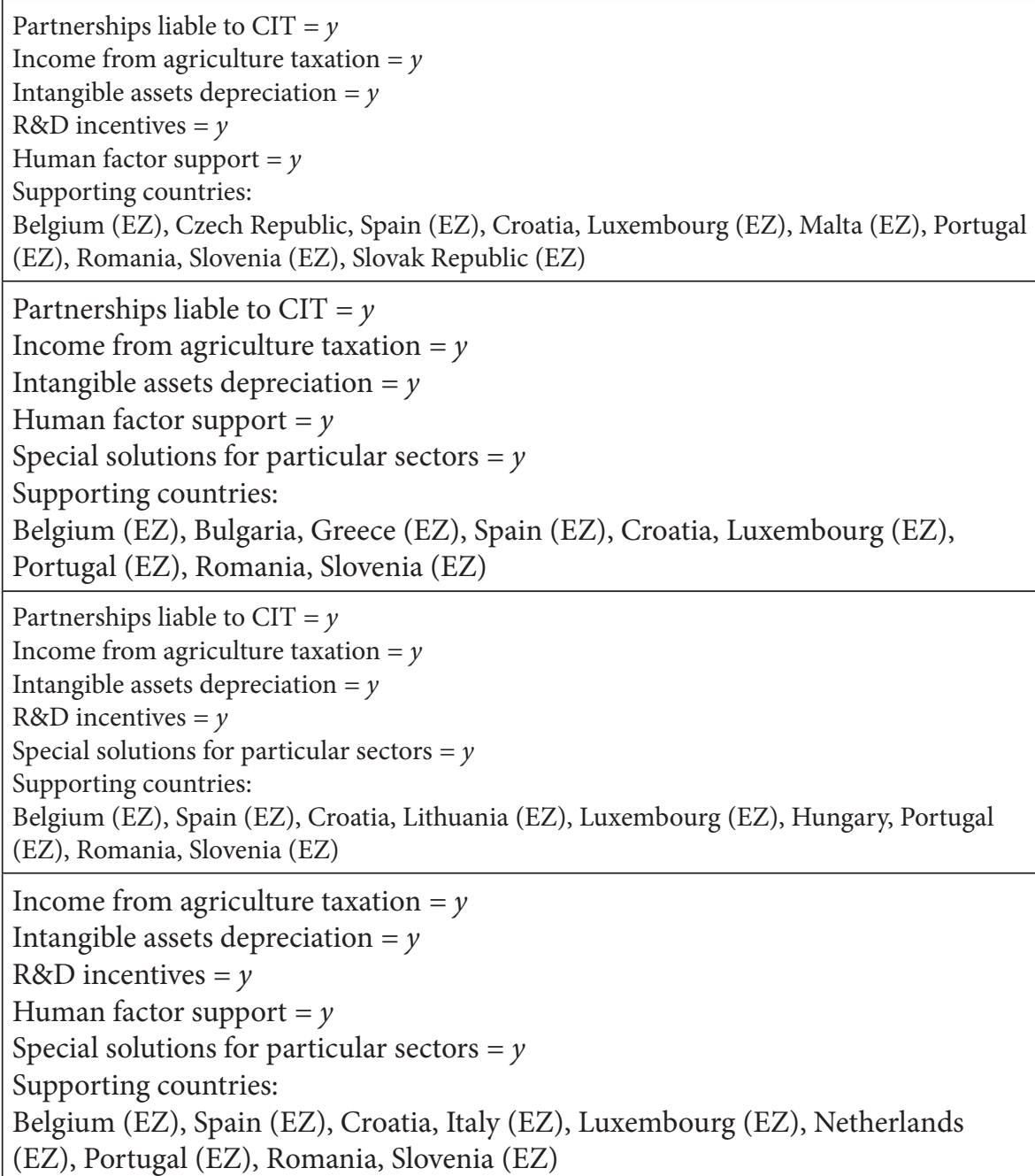

Note: $\mathrm{y}-$ yes.

Source: As in Table 1. 
applied to find (mine) common, most frequently occurring features of CIT in EU countries. The algorithm was implemented in 'arules' package in $\mathrm{R}$ language (Hahsler, Gruen, \& Hornik, 2005). It was applied in order to find frequent item-sets in a table containing in rows sets of values describing CIT features in EU member states. The algorithm uses a principle that larger item-sets are less frequent than smaller ones and eliminates sparse patterns during the search. Numerical values describing tax rates had to be made discrete and converted to nominal items representing ranges of values. For this purpose this was carried out with four equal intervals. To filter out smaller or infrequent item sets the minimum support threshold was set to 0.30 (thus it is required that $30 \%$ of all countries support the pattern) and the minimum item-set size was chosen equal to five items. The analysis included all previously analysed CIT features plus intangible assets depreciation. Results are presented in Table 3.

As a result of the analysis four CIT patterns were identified-one supported by ten states (over $35 \%$ out of EU28) and three supported by nine states (32\% out of EU28). The most frequent CIT pattern (cluster 1) suggests that if the EU state uses an extended tax base (taxation of partnerships, income from agriculture), it provides most often favourable conditions for taxpayers (intangible assets depreciation, R\&D incentives, human factor support ${ }^{12}$ ). Importantly states applying a similar policy for tax base use different tax rates (from 16\% for Romania to 35\% for Malta). They belong then to groups with medium or high tax rates (see Table 2) and, in most cases, are also neighbouring (Belgium-Luxembourg, Spain-Portugal, Czech Republic-Slovak Republic, Croatia-Slovenia-Romania).

The next three clusters show in each case support of nine countries for common patterns combinations (cluster 2 - without R\&D incentives, cluster 3 without incentives for human factor, cluster 4 - without partnerships liable to CIT). Seven countries appear in each of the four clusters which makes up one quarter of the EU (including Great Britain). These countries are: Belgium, Luxembourg, Spain, Portugal, Croatia, Romania, Slovenia (marked in dark green on Figure 5).

There is visible geographical proximity similar to that in the hierarchical analysis. Analysing the next three clusters it can be precisely indicated which features would need to be implemented by each country for them to be included in each cluster. Malta, Czech Republic and Slovakia (from cluster 1) would have to provide incentives for a particular sector or regions. In cluster 2 Bulgaria and Greece would have to introduce incentives for R\&D. In case of cluster 3 Lithuania and Hungary would have to use incentives for human factor support. Finally cluster 4 indicates that Italy and the Netherlands are missing the possibility of corporate taxation on partnerships (marked in light

\footnotetext{
${ }^{12}$ Tax deductions for companies creating new jobs, employing handicapped, elderly people, scientific workers, offering training.
} 


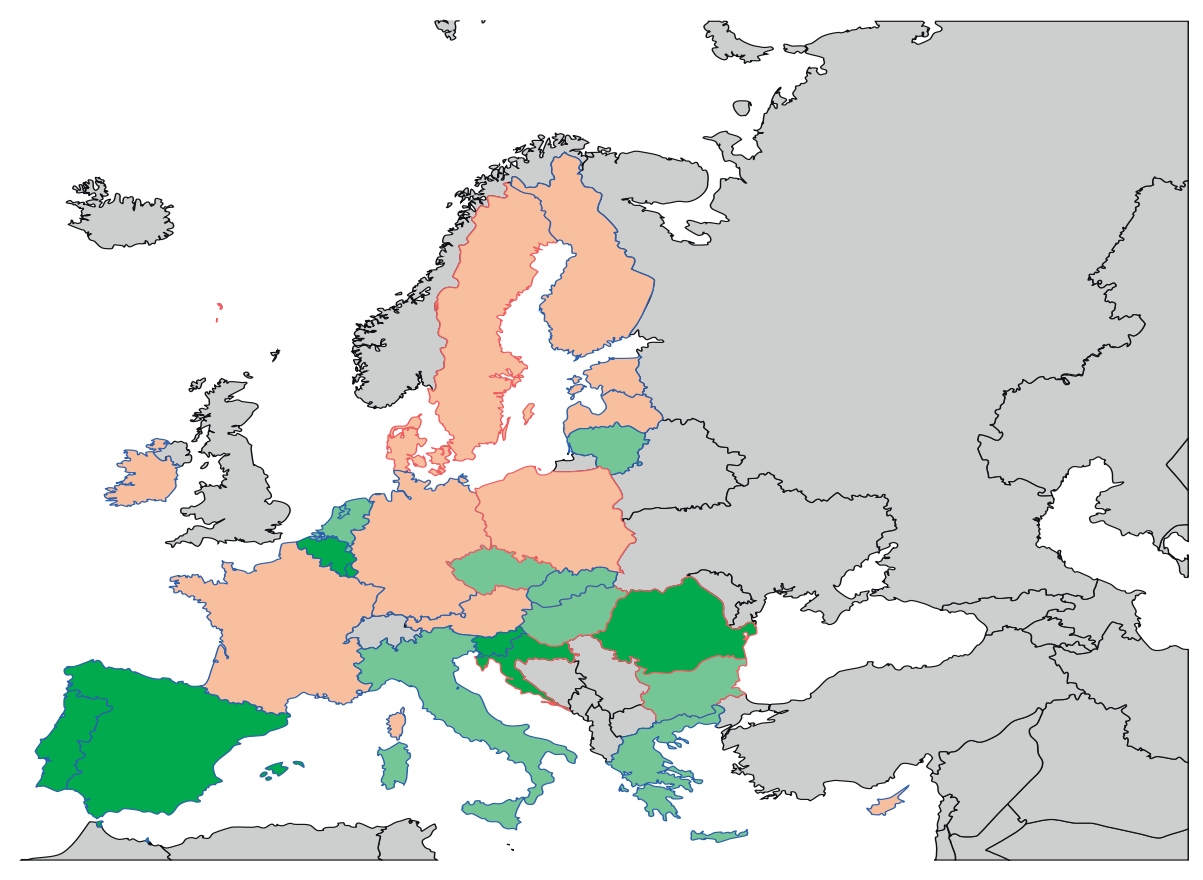

Figure 5. CIT similarity in European Union 2020

Dark green - countries with similar tax bases within the scope of analysed CIT features. Light green - countries missing one of analysed CIT features to belong to the group of countries with similar CIT bases.

Source: Own study.

green on Figure 5). Implementation of these specific changes would increase the number of countries with approached tax bases to sixteen and could move the harmonization process ahead in case the qualified majority voting is binding for taxes. In that case fifteen countries (55\% from twenty seven ) would be enough to vote for the harmonization project. The analysed CIT characteristics constitute only a part of the tax features but the outcome of the analysis shows the importance of the geographic key in introducing similar tax solutions. Considering the fact that states compete not only with tax rates but also with tax bases further convergence of tax bases can be expected. The greater convergence shall in turn facilitate the implementation of common rules proposed in CCCTB draft.

\section{Conclusions and discussion}

CIT in the EU is differentiated despite the harmonization efforts of the European Commission. As mentioned differentiation concerns mainly tax rates. The structures of tax bases and the approach to the taxpayers, although differentiated, 
are converging (incentives, depreciation periods) and may be used for the tax harmonization. Using similar tax base solutions is bringing countries closer and creates a firm ground for unenforced tax harmonization.

Tax harmonization understood as the unification of rules used for determining tax bases is possible as the convergence in tax policies and structures is visible in many EU economies. The geographical criterion still plays an important role in tax convergence. Neighbouring countries apply similar CIT solutions (especially in case of tax incentives). Taking into account that tax bases can also become a tool of harmful tax competition their harmonization could make such competition more fair by determining rules as it is predicted in CCCTB directive proposition. Harmonization understood as tax approximation will always be a kind of compromise and never fully satisfy all EU member states. It is worth considering that no better solution has been proposed so far. The ground for harmonization has been prepared, tax policies are partly converging and the implementation of harmonization is, in fact, highly dependent on EU states' will to do so. In the case of QMV in states with already similar tax solutions, making a decision for harmonization will be easier.

\section{References}

Baldwin, R. \& Krugman, P. (2004). Agglomeration, integration and tax harmonisation. European Economic Review, 48(1), 1-23.

Barry, F. (2010). The case against corporation tax harmonisation and tax-base consolidation: A view from Ireland, 2010. Retrieved from https://doi.org/10.1177/1024258909357879

Bettendorf, L., Devereux, M., Horst, A., Loretz, S., Mooij, R., Jacobs, B., \& Wasmer, E. (2010). Corporate tax harmonization in the EU (with discussion). Economic Policy, 25(63), 537-590.

Bolkestein, F. (2000). Taxation and competition: The realization of the internal market. European Taxation, 40(9), 401-406.

Broll, U., Kemnitz, A., \& Mukherjee, V. (2019). Globalization, inequality and economic policy. Economics and Business Review, 5(1), 3-11.

Bustos-Contell, E., Climent-Serrano, S., \& Labatut-Serer, G. (2020). Tax incentives: An effective mechanism to achieve EU harmonization?. Journal of Business Accounting and Finance Perspectives, 2, 1-13.

Clifford, S. (2019). Taxing multinationals beyond borders: Financial and locational responses to CFC rules. Journal of Public Economics, 173, 44-71.

Council of the European Union. (1997). Conclusions of the ECOFIN Council Meeting on 1 December 1997 concerning taxation policy, 98/C/2/01. Retrieved December 5, 2020 from https:/ec.europa.eu/taxation_customs/sites/taxation/files/resources/ documents/coc_en.pdf

Commission de la Communauté Économique Européenne. (1962). Rapport du Comité Fiscal et Financier. Retrieved December 5, 2020 from http://aei.pitt.edu/33686/1/ A220.pdf 
Commission of the European Communities. Towards tax co-ordination in the European Union. Retrieved December 5, 2020 from https://eur-lex.europa.eu/legal-content/ EN/TXT/PDF/?uri=CELEX:51997DC0495\&from=EN

Commission of the European Communities. (1970). Corporation tax and the individual income tax in the European Communities, 1970/15.

Communication from the Commission to the European Parliament, the European Council and the Council of 15 January 2019. Towards a more efficient and democratic decision making in EU tax policy (COM(2019) 0008).

Devereux, M. \& Loretz, S. (2010). Evaluating neutrality properties of corporate tax reforms. Oxford: Oxford University Centre for Business Taxation.

Dosser, D. (1973). British taxation and the common market. London: Charles Knight.

European Commission. DG Taxation and Customs Union, based on Eurostat data. retrieved from https://ec.europa.eu/taxation_customs/business/economic-analysistaxation/data-taxation_en

European Commission. (2016). Impact assessment accompanying the document. Proposals for a Council Directive on a Common Corporate Tax Base and a Common Consolidated Corporate Tax Base (CCCTB).

European Commission. (2018). Tax policies in the European Union Survey. Retrieved from https://ec.europa.eu/taxation_customs/sites/taxation/files/tax_policies_survey_2018.pdf

Galili, T. (2015). Dendextend: an R package for visualizing, adjusting, and comparing trees of hierarchical clustering. Bioinformatics. doi:10.1093/bioinformatics/btv428

Hahsler, M., Gruen, B., \& Hornik, K. (2005). arules-A computational environment for mining association rules and frequent item sets. Journal of Statistical Software, 14(15), 1-25. doi:10.18637/jss.v014.i15

International Monetary Fund. (2018). Junji Ueda, Estimating the Corporate Income Tax Gap: The RA-GAP. Retrieved from https:/www.imf.org/en/Publications/ TNM/Issues/2018/09/12/Estimating-the-Corporate-Income-Tax-Gap-The-RAGAP-Methodology-4589

James, S. \& Oats, L. (1998). Tax harmonisation and the case of corporate taxation. Revenue Law Journal, 8.

Korečko, J. \& Ondrijová, I. (2019). Analysis of the selected indicators of the tax burden on entrepreneurs in the EU. doi:https://doi.org/10.31410/ITEMA.S.P.2019.45

Lukáčová, M., Korečko, J., Jenčová, S., \& Jusková, M. (2020). Analysis of selected indicators of tax competition and tax harmonization in the EU. Entrepreneurship and Sustainability Issues, 8(1), 123-137. Retrieved from http://doi.org/10.9770/ jesi.2020.8.1(8)

Małecka-Ziembińska, E. (2010). Wybrane zagadnienia konkurencji podatkowej oraz ich egzemplifikacja na przykładzie podatku dochodowego od osób fizycznych. In T. Juja (Ed.), Dylematy i wyzwania finansów publicznych (pp. 451-467). Zeszyty Naukowe Uniwersytetu Ekonomicznego w Poznaniu, 141.

Mooij, R. \& Ederveen, S. (2003). Taxation and foreign direct investment: A synthesis of empirical research. International Tax and Public Finance, 10, 673-693.

Mooij, R., Liu, L., \& Prihardini, D. (2019). An assessment of global formula apportionment. (IMF Working Paper).

Pîrvu, D. (2012). Corporate income tax harmonization in the European Union. London: Macmillan. 
Prest, A. (1979). Fiscal policy. In P. Coffey (Ed.), Economic policies of the common market (pp. 69-97). London: Macmillan.

R Core Team. (2020). R: A language and environment for statistical computing. $R$ Foundation for Statistical Computing. Vienna. Retrieved October, 2020 from http://www.R-project.org/

Ruding Report. (1992). Report of the Committee of Independent Experts on Company Taxation.

Šimková, N. (2015). The hierarchical clustering of tax burden in the EU27. Journal of Competitiveness, 7(3), 95-109.

Sinn, H. (1990). Tax harmonization and tax competition in Europe. European Economic Review, 34, 489-504.

Sørensen, P. (2004). Company tax reform in the European Union. International Tax and Public Finance, (11), 91-115.

Tulai, C. \& Serbu, S. (2005). Comparative taxation and fiscal harmonization. Cluj-Napoca: Casa Cărții de Știință.

Van der Hoek, P. (2003). Tax harmonization and competition in the European Union. eJournal of Tax Research, 1(1), 19-36.

\section{Legal acts}

Consolidated version of The Treaty on the functioning of the European Union, Official Journal of the European Union, 26 October 2012. C/326/47. Retrieved December 5, 2020 from https://eur-lex.europa.eu

Convention 90/436/EEC on the elimination of double taxation in connection with the adjustment of profits of associated enterprises.

Council Directive 2003/49/EC on a common system of taxation applicable to interest and royalty payments made between associated companies of different Member States.

Council Directive 2009/133/EC on the common system of taxation applicable to mergers, divisions, partial divisions, transfers of assets and exchanges of shares concerning companies of different Member States and to the transfer of the registered office of an SE or SCE between Member States.

Council Directive 2011/16/EU of 15 February 2011 on administrative cooperation in the field of taxation and repealing Directive 77/799/EEC.

Council Directive 2011/96/EU on the common system of taxation applicable in the case of parent companies and subsidiaries of different Member States. This directive replaced in 2011 Directive 90/435 on the common system of taxation applicable in the case of parent companies and subsidiaries of different Member States.

Directive (EU) 2016/1164 of 12 July 2016 laying down rules against tax avoidance practices that directly affect the functioning of the internal market.

Treaty of Nice amending The Treaty on European Union, The Treaties establishing The European Communities and certain related acts (Official Journal of the European Union 2001/C 80/01).

The Treaty amending The Treaty on European Union and The Treaty establishing The European Community (2007/C 306/01). 


\begin{abstract}
Aims and Scope
The Economics and Business Review is a quarterly journal focusing on theoretical, empirical and applied research in the fields of Economics and Corporate and Public Finance. The Journal welcomes the submission of high quality articles dealing with micro, mezzo and macro issues well founded in modern theories and relevant to an international audience. The EBR's goal is to provide a platform for academicians all over the world to share, discuss and integrate state-of-the-art Economics and Finance thinking with special focus on new market economies.
\end{abstract}

\title{
The manuscript
}

1. Articles submitted for publication in the Economics and Business Review should contain original, unpublished work not submitted for publication elsewhere.

2. Manuscripts intended for publication should be written in English, edited in Word in accordance with the APA editorial guidelines and sent to: secretary@ebr.edu.pl. Authors should upload two versions of their manuscript. One should be a complete text, while in the second all document information identifying the author(s) should be removed from papers to allow them to be sent to anonymous referees.

3. Manuscripts are to be typewritten in 12' font in A4 paper format, one and half spaced and be aligned. Pages should be numbered. Maximum size of the paper should be up to 20 pages.

4. Papers should have an abstract of about 100-150 words, keywords and the Journal of Economic Literature classification code (JEL Codes).

5. Authors should clearly declare the aim(s) of the paper. Papers should be divided into numbered (in Arabic numerals) sections.

6. Acknowledgements and references to grants, affiliations, postal and e-mail addresses, etc. should appear as a separate footnote to the author's name a, b, etc and should not be included in the main list of footnotes.

7. Footnotes should be listed consecutively throughout the text in Arabic numerals. Cross-references should refer to particular section numbers: e.g.: See Section 1.4.

8. Quoted texts of more than 40 words should be separated from the main body by a four-spaced indentation of the margin as a block.

9. References The EBR 2017 editorial style is based on the 6th edition of the Publication Manual of the American Psychological Association (APA). For more information see APA Style used in EBR guidelines.

10. Copyrights will be established in the name of the E\&BR publisher, namely the Poznań University of Economics and Business Press.

More information and advice on the suitability and formats of manuscripts can be obtained from:

\section{Economics and Business Review}

al. Niepodległości 10

61-875 Poznań

Poland

e-mail: secretary@ebr.edu.pl

www.ebr.edu.pl 


\section{Subscription}

Economics and Business Review (E\&BR) is published quarterly and is the successor to the Poznan University of Economics Review. The E\&BR is published by the Poznań University of Economics and Business Press.

Economics and Business Review is indexed and distributed in Claritave Analytics, DOAJ, ERIH plus, ProQuest, EBSCO, CEJSH, BazEcon, Index Copernicus and De Gruyter Open (Sciendo).

Subscription rates for the print version of the E\&BR: institutions: 1 year $-€ 50.00$; individuals: 1 year $-€ 25.00$. Single copies: institutions - $€ 15.00$; individuals - $€ 10.00$. The E\&BR on-line edition is free of charge. 